\title{
Editorial: Some reflections on transport infrastructure delivery in South Africa
}

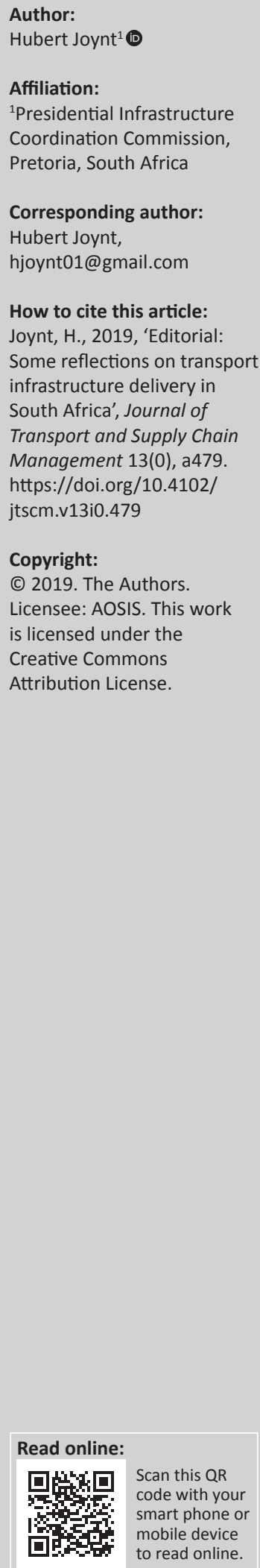

\section{Introduction}

Like any country in the world, providing infrastructure for the economy and communities is one of the main ways South Africa will realise inclusive and jobs-rich growth. Quality, affordable infrastructure, which includes transport infrastructure, raises economic productivity, permits economic expansion and allows marginalised households and communities to take advantage of new opportunities. Infrastructure is critical to strengthen key value chains across our economy (Presidential Infrastructure Coordinating Commission [PICC] 2012:5). Infrastructure investment is also a key priority of the National Development Plan.

There are many aspects to transport infrastructure and the provision thereof. In a country like South Africa, with serious budget constraints given the poor economic performance and the legacy of the state-capture project, the allocation and expenditure of funds for the provision and maintenance of transport infrastructure are of real significance. In this regard, the editorial focuses on the following aspects:

- the current state of transport infrastructure

- transport infrastructure financing and delivery trends.

\section{Current state of transport infrastructure}

The South African Institute of Civil Engineers (SAICE) (2017:4) states that infrastructure report cards that grade the condition of infrastructure are not that common as most of these focus on the level of commercial activity in the construction sector. The condition of South Africa's transport infrastructure has a definite impact on the country's global competitiveness.

The Global Competitiveness Report is a yearly report published by the World Economic Forum (WEF), which ranks countries based on the Global Competitiveness Index. Although the quality of all infrastructure sectors is analysed by this index, the focus of this editorial is only on transport infrastructure. Figure 1 reflects the impact of the quality of transport infrastructure on South Africa's global competitiveness ranking.

It is evident from Figure 1 that the quality of the South African infrastructure has reduced from the previous period's quality ranking (now in 72nd place compared to the previous 59th place). The quality of transport infrastructure has also been reduced over this period. Of significance is that this decline in the ranking of the country occurred over a relatively short period of time. Although down from the 2015 to 2016 Report, the quality of air transport infrastructure had the highest ranking of 25, whilst that of roads transport had the lowest ranking of 50 as per the 2017-2018 Report. This declining trend in the quality of transport infrastructure will have an adverse impact on the competitiveness of South Africa with other countries and will add to logistics and other costs.

Table 1 is a transport infrastructure barometer based on a summary of several sources that described or analysed the South African Transport Infrastructure performance or condition.

The table underlines the relatively poor performance of transport infrastructure delivery in South Africa. Most transport infrastructure sub-sectors reflected downward trends in their grading reports. This dismal state of transport infrastructure performance in South Africa is further aptly depicted by Figure 2.

From both Table 1 and Figure 2 it is evident that the condition of South Africa's transport infrastructure is declining. Of the 18 transport infrastructure sub-sectors, the conditions of 10 were reported as having declined when compared to the previous review period. Only two sub-sectors have shown an improvement over the previous period, namely, the condition of provincial road infrastructure and 


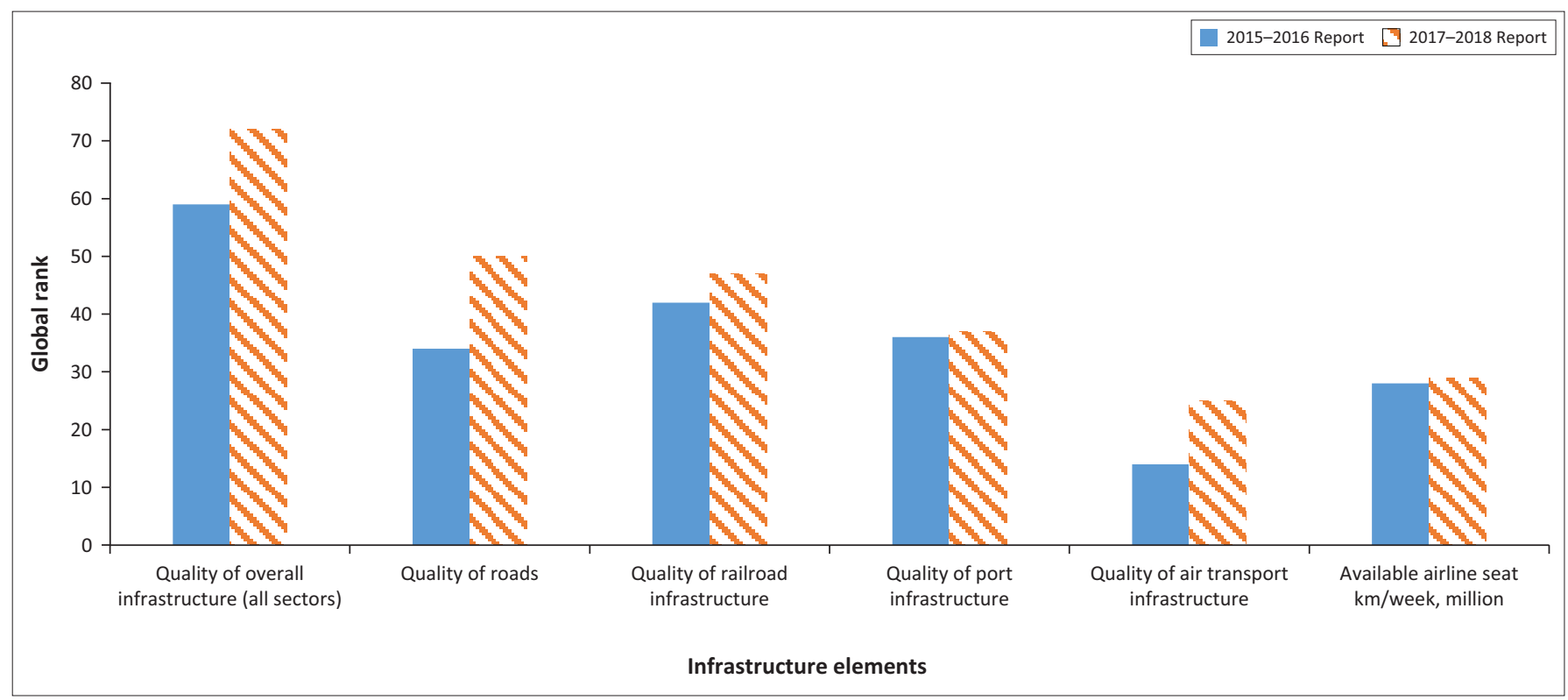

Source: Adapted from World Economic Forum (WEF), 2015, The global competitiveness report 2015-2016, World Economic Forum, Geneva; World Economic Forum (WEF), 2017, The global competitiveness report 2017-2018, World Economic Forum, Geneva.

FIGURE 1: South African global competitiveness ranking on transport infrastructure.

TABLE 1: South African transport infrastructure barometer.

\begin{tabular}{|c|c|c|c|c|}
\hline Sector & Sub-sector & Review trend & Score & Source \\
\hline \multirow[t]{6}{*}{ Roads } & National roads & Stable & B & SAICE \\
\hline & Paved provincial roads & Upwards & $\mathrm{D}$ & SAICE \\
\hline & Paved metropolitan roads & Stable & C- & SAICE \\
\hline & Other paved municipal roads & Downwards & D- & SAICE \\
\hline & Provincial, metropolitan and municipal gravel roads & Stable & $\mathrm{E}$ & SAICE \\
\hline & Quality of roads & Downwards & $\mathrm{D}$ & WEF adapted \\
\hline \multirow[t]{2}{*}{ Airports } & Airports Company of South Africa (ACSA) owned & Stable & $\mathrm{B}+$ & SAICE \\
\hline & Quality of air transport infrastructure & Downwards & A & WEF adapted \\
\hline Public transport & Distance from facilities & Downwards & No score & Stats SA Adapted \\
\hline \multirow[t]{2}{*}{ Ports } & Commercial ports & Stable & B- & SAICE \\
\hline & Quality of port infrastructure & Downwards & $\mathrm{D}+$ & WEF adapted \\
\hline \multirow[t]{5}{*}{ Rail } & Heavy haul freight lines & Stable & $\mathrm{B}+$ & SAICE \\
\hline & General freight lines & Downwards & C & SAICE \\
\hline & Branch lines & Downwards & D- & SAICE \\
\hline & Passenger lines (Gautrain) & New item & A & SAICE \\
\hline & Quality of railroad infrastructure & Downwards & $\mathrm{E}$ & WEF adapted \\
\hline \multirow[t]{2}{*}{ Logistics } & Cross-border trade & Upwards & $\mathrm{F}$ & World Bank adapted \\
\hline & Infrastructure & Downwards & $\mathrm{C}$ & World Bank adapted \\
\hline \multirow{2}{*}{$\begin{array}{l}\text { Overall grade (all } \\
\text { infrastructure) }\end{array}$} & Quality of overall infrastructure & Downwards & $\mathrm{D}$ & WEF adapted \\
\hline & Overall grade & Downwards & $\mathrm{D}+$ & SAICE \\
\hline
\end{tabular}

Source: Adapted from South African Institution of Civil Engineers (SAICE), 2017, SAICE 2017 Infrastructure report card for South Africa, South African Institution of Civil Engineers, Midrand; South African Institution of Civil Engineers (SAICE), 2011, SAICE Infrastructure report card for South Africa 2011, South African Institution of Civil Engineers, Midrand; World Economic Forum (WEF), 2015, The global competitiveness report 2015-2016, World Economic Forum, Geneva; World Economic Forum (WEF), 2017, The global competitiveness report 2017-2018, World Economic Forum, Geneva; Statistics South Africa (Stats SA), 2016, General household survey, Statistical Release P0318, Statistics South Africa, Pretoria; Statistics South Africa (Stats SA), 2017, General household survey, Statistical Release P0318, Statistics South Africa, Pretoria; World Bank, 2016, Connecting to compete 2016: Trade logistics in the global economy: The logistics performance index and its indicators, World Bank, Washington, DC.

SAICE, South African Institution of Civil Engineers; Stats SA, Statistics South Africa; WEF, World Economic Forum.

cross-border trade infrastructure. This situation may be because of a lack of funding for transport infrastructure implementation and maintenance. The next section will discuss issues pertaining to transport infrastructure financing and delivery.

\section{Transport infrastructure financing and delivery}

The National Treasury (NT) (2019a:140) states that all publicsector infrastructure spending over the medium-term expenditure framework (MTEF) period is estimated to be at R864.9 billion. In this regard, it is important to consider the definition of infrastructure, namely (NT 2019a):

Infrastructure is defined broadly, including spending on new assets; replacements; maintenance and repairs; upgrades and additions; and rehabilitation, renovation and refurbishment of assets. Capital and interest payments are also included in the definition. In contrast, 'capital spending' typically excludes maintenance and finance charges. (p. 140) 
The NT Budget Review provides transport infrastructure highlights with data that include infrastructure financed at national, provincial and local government levels with spending estimates received from state-owned companies and other public entities (NT 2019a:140). The expenditure and estimates (MTEF 2019/2020 to 2021/2022) on transport infrastructure are presented in Figure 3.

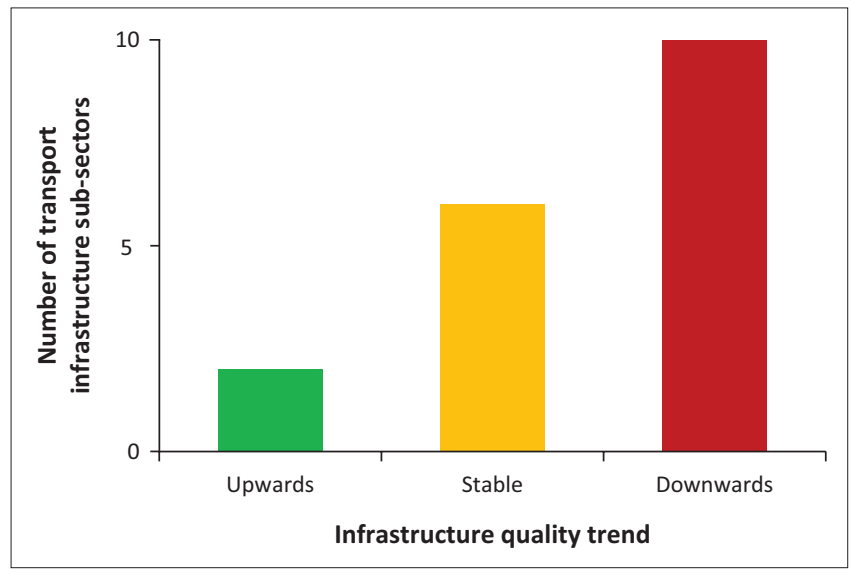

FIGURE 2: Trend in transport infrastructure provision for South Africa.
From Figure 3 it is deduced that the transport and logistics infrastructure financing amounted from approximately $28 \%$ $(2016 / 2017)$ to $38 \%(2021 / 2022)$ of the entire infrastructure budget of the government. This is by far the largest budgetary allocation of any infrastructure sector. To maintain this financial allocation, the transport sector has the responsibility to ensure that transport infrastructure is adequately implemented and maintained. Figure 4 depicts how well this funding allocation is being spent (MTEF figures of 2019/2020 onwards are based on expenditure trends).

Figure 4 reflects that South Africa has on average a 20.4\% underspending record for transport infrastructure. This underspending can total as much as R150 billion (for the 7-year reporting period) if this trend continues for the MTEF period. This is a significant underspending and the opportunity cost associated with this poor performance can be brought into perspective when comparing this amount to the Gautrain project that cost approximately R30bn. Unfortunately, this underspending performance is further exaggerated by the fact that this spending cannot be considered as wholly effective spending. This argument is based on the

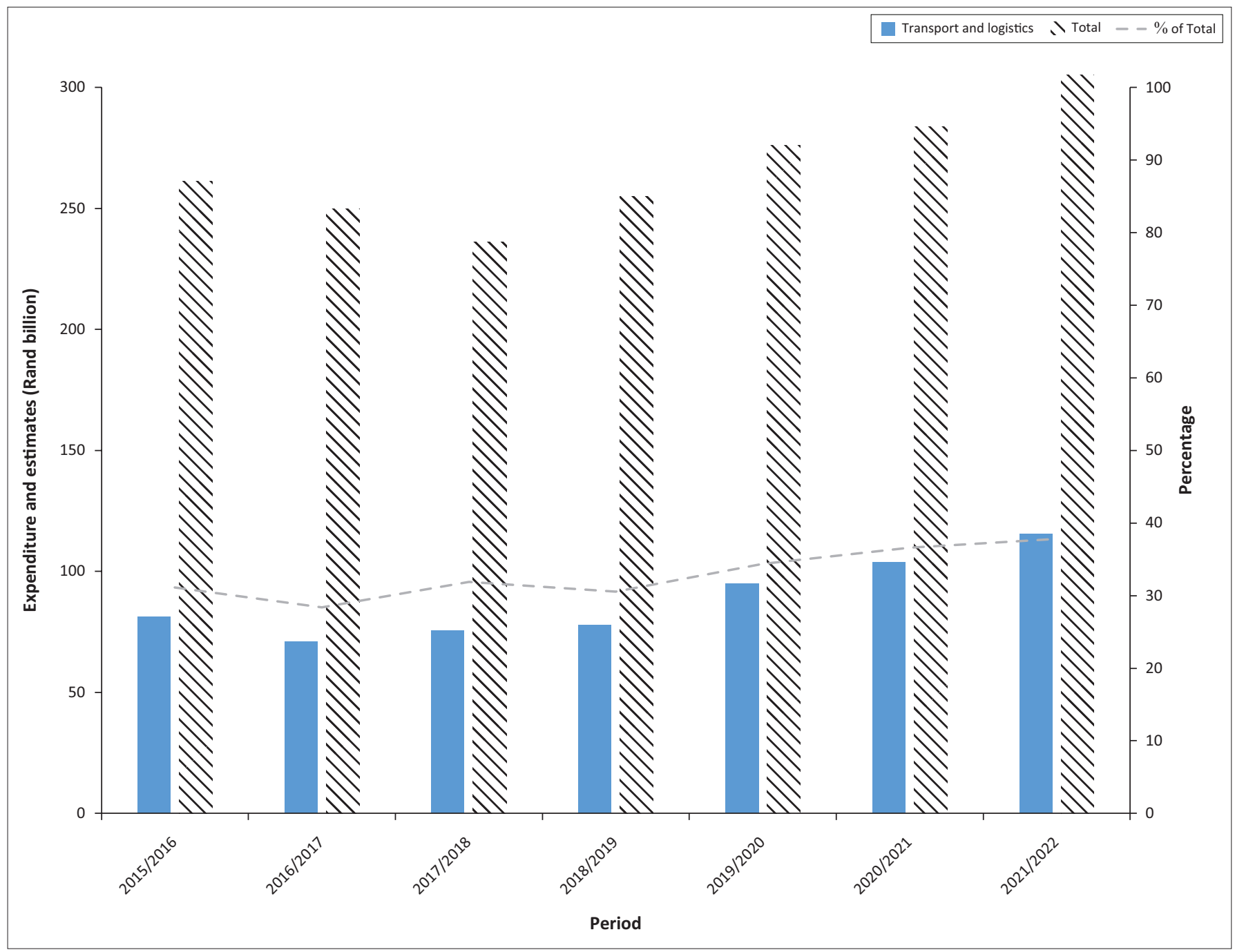

Source: Derived from National Treasury (NT), 2019a, Budget review 2019, National Treasury, Pretoria.

FIGURE 3: Infrastructure expenditure and estimates in South Africa (2015/2016 to 2021/2022). 


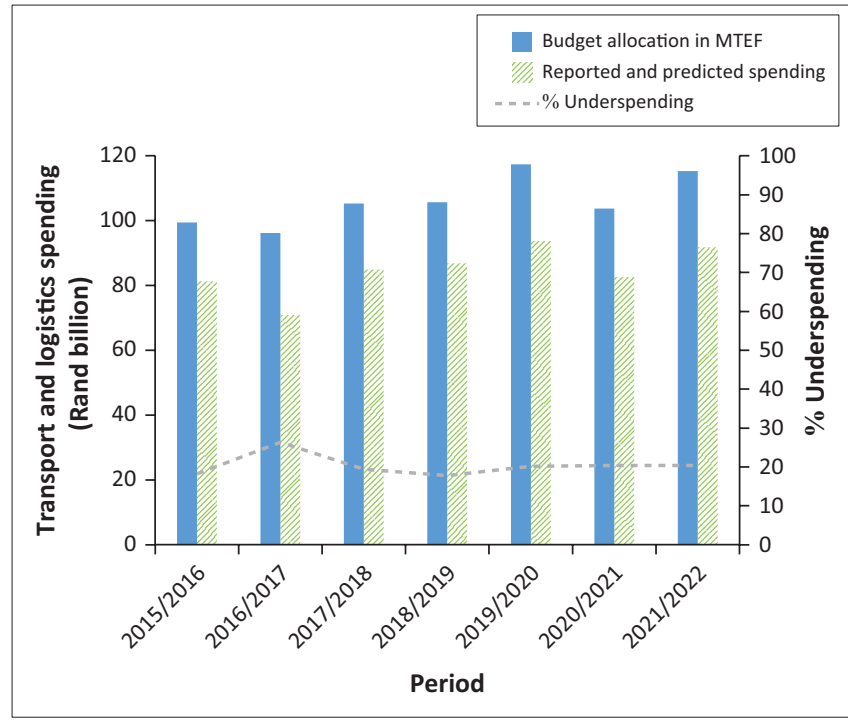

Source: Derived from National Treasury (NT), 2016, Budget review 2016, National Treasury, Pretoria; National Treasury (NT), 2017, Budget review 2017, National Treasury, Pretoria; National Treasury (NT), 2018, Budget review 2018, National Treasury, Pretoria; National Treasury (NT), 2019a, Budget review 2019, National Treasury, Pretoria.

FIGURE 4: Transport infrastructure spending in South Africa (2015/2016 to 2021/2022).

fact that spending occurred during a period characterised by the state-capture project and poor spending practices by government. The report by the Auditor General (2018) on National and Provincial Audit Outcomes summarised the spending by the South African government as follows:

- That in general the national audit outcomes regressed (only $25 \%$ of auditees provided quality financial statements).

- That there was an increase in the number of audits not completed compared to the previous year.

- That there is serious weakness in the financial management of national and provincial government.

- That there was little improvement in the management and delivery of key government projects.

- That there was an increase from $64 \%$ to $72 \%$ of the auditees that materially did not comply with financial and supply chain management legislation.

- That irregular expenditure remained high at R51bn.

From the above it can be deduced that the provision of transport infrastructure will remain under pressure if infrastructure is not properly planned, implemented, maintained and managed. It is argued that effective investment can be improved through proper transport economic analyses and feasibility studies. Improved financial management practices of transport projects are clearly needed. An increase in maintenance budgets will assist to ensure that transport infrastructure can reach its designed economic lifespan.

\section{Summary and concluding remarks}

This article identified both the positive aspects and potential challenges of transport infrastructure provision in South Africa. On the positive side, transport infrastructure receives the bulk of infrastructure funding allocation and this is expected to continue for at least the current MTEF period. Despite this, the ranking of South Africa on the Global Competitiveness Index regarding infrastructure has declined from 59th to 72 nd position over a 2 -year period. The same declining trend was reported for transport infrastructure. Other concerns relate to the underspending of capital budgets.

Some of these challenges can be addressed by ensuring effective investment in transport infrastructure projects. This can be achieved through rigorous economic feasibility evaluations and improved financial management practices for transport infrastructure projects. Lastly, the prioritisation of maintenance programmes for transport infrastructure projects should be expedited.

\section{Acknowledgements}

The author would like to thank the JTSCM for inviting him to be the author for the editorial.

\section{Competing interests}

The author declares that no competing interests exist.

\section{Author's contributions}

I declare that I am the sole author of this research article.

\section{Ethical considerations}

This article followed all ethical standards for research without direct contact with human or animal subjects.

\section{Funding information}

This research received no specific grant from any funding agency in the public, commercial or not-for-profit sectors.

\section{Data availability statement}

Data sharing is not applicable to this article as no new data were created or analysed in this study.

\section{Disclaimer}

The views and opinions expressed in this article are those of the author and do not necessarily reflect the official policy or position of any affiliated agency of the author.

\section{References}

Auditor General (AG), 2018, Consolidated general report on national and provincia audit outcomes: PFMA 2017-18, Auditor General, Pretoria.

National Treasury (NT), 2016, Budget review 2016, National Treasury, Pretoria. National Treasury (NT), 2017, Budget review 2017, National Treasury, Pretoria. National Treasury (NT), 2018, Budget review 2018, National Treasury, Pretoria. National Treasury (NT), 2019a, Budget review 2019, National Treasury, Pretoria. National Treasury (NT), 2019b, Economic transformation, inclusive growth, and competitiveness: Towards an economic strategy for South Africa, National Treasury, Pretoria. 
Presidential Infrastructure Coordinating Commission (PICC), 2012, A summary of the South African National infrastructure plan, Presidential Infrastructure Coordinating Commission, Pretoria.

South African Institution of Civil Engineers (SAICE), 2011, SAICE Infrastructure report card for South Africa 2011, South African Institution of Civil Engineers, Midrand.

South African Institution of Civil Engineers (SAICE), 2017, SAICE 2017 Infrastructure report card for South Africa, South African Institution of Civil Engineers, Midrand.

Statistics South Africa (Stats SA), 2016, General household survey, Statistical Release P0318, Statistics South Africa, Pretoria.
Statistics South Africa (Stats SA), 2017, General household survey, Statistical Release P0318, Statistics South Africa, Pretoria.

World Bank, 2016, Connecting to compete 2016: Trade logistics in the global economy: The logistics performance index and its indicators, World Bank, Washington, DC.

World Bank, 2018, Connecting to compete 2018: Trade logistics in the global economy: The logistics performance index and its indicators, World Bank, Washington, DC.

World Economic Forum (WEF), 2015, The global competitiveness report 2015-2016, World Economic Forum, Geneva.

World Economic Forum (WEF), 2017, The global competitiveness report 2017-2018, World Economic Forum, Geneva. 